\title{
Six novel coding SNPs of the nucleophosmin 1 (NPM1) gene and their associations with growth traits in bovine (Brief Report)
}

\section{Sechs SNPs in kodierende Abschnitten des Nukleophosmin 1 (NPM1) Gens und ihre Assoziation mit Wachstumsmerkmalen beim Rind (Brief Report)}

YONGZHEN HUANG ${ }^{1}$, ENPING ZHANG ${ }^{1}$, ZHUANJIAN LI ${ }^{1}$, JING WANG ${ }^{1}$, YONGTAO HUAI $^{1}$, LIANG MA ${ }^{1}$, FUYING CHEN ${ }^{1}$, XIANYONG LAN ${ }^{1}$, CHUZHAO LEI $^{1}$, JUQIANG WANG $^{3}$, XINGTANG FANG ${ }^{2}$ and HONG CHEN ${ }^{1}$

${ }^{1}$ College of Animal Science and Technology, Northwest A\&F University, Shaanxi Key Laboratory of Molecular Biology for Agriculture, Yangling, Shaanxi, People's Republic of China, ${ }^{2}$ Institute of Cellular and Molecular Biology, Xuzhou Normal University, Xuzhou, Jiangsu, People's Republic of China, ${ }^{3}$ Research Center of Cattle Engineering Technology in Henan; Zhengzhou Henan, People's Republic of China

\section{Background}

The Nucleophosmin 1 (NPM1) gene encodes a multifunctional nucleolar phosphoprotein that has crucial roles in the control of different aspects of cell growth and homeostasis, such as ribosome biogenesis, centrosome duplication, cell cycle progression, apoptosis and cell differentiation (GRISENDI et al. 2006, NAOE et al. 2006). As mutants of NPM1 gene impact protein synthesis, NPM1 is an essential protein in mouse development and cell growth (MAGGI et al. 2008). The bovine NPM1 gene contains one exon and locates at chromosome 9. In previous work, the 12-bp deletion was detected in bovine NPM1 gene coding region. (HUANG et al. 2010). In this study, the coding region of bovine NPM1 gene has been scanned by PCR-SSCP, DNA sequencing and forced PCR-RFLP methods for SNPs in 1032 individuals belonging to four Chinese cattle breeds. Association of six mutations of NPM1 gene with growth traits was analyzed.

\section{Procedures}

Primer sequences and conditions:

Two pairs of primers P1 and P2 were designed based on bovine NPM1 gene (GenBank acc. no. NC_007307).

P1 P1-F1: 5'-GCT TCT CTC CCA CAT AAG-3' (nt75-92)

P1-R1: 5'-CTT CAA CCG TAA GAC CAC-3' (nt400-417)

P1-R2: 5'-TAC AGA AAT GAA ATA AGA CG-3' (nt1027-1046)

P2 P2-F1: 5'-CAC CAC CTG TGG TCT TAC-3' (nt392-409)

P2-R1: 5'-CTT CCT CAT CAA AAT CGT-3' (nt650-667).

One pair of primers was designed to amplify a $972 \mathrm{bp}$ fragment (checked by DNA sequencing; primers: P1-F1/P1-R2) contain the CDS region (nt109-993) of the bovine NPM1 gene. 
The $15 \mu \mathrm{L}$ PCR amplification contained $30 \mathrm{ng}$ of genomic DNA, $0.20 \mathrm{mM}$ dNTP, $2.5 \mathrm{mM}$ $\mathrm{MgCl}_{2}$, and $0.5 \mathrm{U}$ Taq DNA polymerase (MBI). The PCR was performed using the following program: $94^{\circ} \mathrm{C}$ for $3 \mathrm{~min}$ followed by 34 cycles of $94^{\circ} \mathrm{C}$ for $30 \mathrm{~s}$, annealing at $56.5^{\circ} \mathrm{C}$ and $56^{\circ} \mathrm{C}$ corresponding two different pairs of primers for $30 \mathrm{~s}, 72^{\circ} \mathrm{C}$ for $30 \mathrm{~s}$ and a final extension at $72^{\circ} \mathrm{C}$ for $10 \mathrm{~min}$.

\section{$P C R-S S C P, D N A$ sequencing and forced PCR-RFLP}

Aliquots of $5 \mu \mathrm{L} \mathrm{PCR}$ products were mixed with $5 \mu \mathrm{L}$ denaturing solution, heated for $10 \mathrm{~min}$ at $98^{\circ} \mathrm{C}$ and chilled on ice. Denatured DNA was subjected to $12 \%$ PAGE in constant voltage $(200 \mathrm{~V}$ ) for $2.5 \sim 3.0 \mathrm{~h}$. The gel was stained with $0.1 \%$ silver nitrate (WANG et al. 2009).

P1-F1/P1-R1 and P2-F1/P2-R1 provide two overlapping PCR fragments used to detect polymorphisms by PCR-SSCP. The PCR fragments from different SSCP patterns were selected for sequencing.

Two novel PCR-RFLPs were designed to detect for these polymorphisms. The primers sequences used were:

P1-F2: 5'TGA TGA AAA TGA GCA CCA GAT AT 3' (ECORV, GAT^ATC; nt216-235)

P2-R2: 5' GGC AGA ACG CTT TCC AGA TAA GCT 3' (Hind III, A^AGCTT; nt517-540).

The $205 \mathrm{bp}$ fragment of the NPM1 gene was amplified by P1-F2 and P1-R1 primers. The naturally-occurring $>T<$ nucleotide at $n t 232$ was substituted by an $>A$ < in the forward primer (underlined) in order to introduce a new recognition site (GAT^ATC) for the EcoRV (MBI, Vilnius, Lithuania) restriction endonuclease (size: 205 bp; primers: P1-F2/P1-R1). Also, the new reverse P2-R2 primer was designed to produce a new HindIII (MBI) restriction site (A^AGCTT) in PCR products (size: 149bp; primers: P2-F1/P2-R2) by the same method. Thus, the amplification contains two recognition sites for the detection of SNPs. Then, aliquots of $10 \mu \mathrm{L} \mathrm{PCR}$ products were digested with $10 \mathrm{U}$ EcoRV and Hind III for $6 \mathrm{~h}$ at $37^{\circ} \mathrm{C}$, respectively. The digested products were detected by electrophoresis in $3.0 \%$ agarose gel stained with ethidium bromide, respectively.

\section{Results}

SNPs were detected in the exon in 1032 unrelated cattle from four cattle breeds in China (Nanyang - 262, Qinchuan - 235, Jiaxian - 441, Chinese Holstein - 94). Comparison between the nucleotide sequences of the bovine NPM1 gene and the above sequences revealed six mutations (GenBank acc no. NC_007307: g.236C >G, 489G>A, 516G>A, $624 \mathrm{~T}>\mathrm{C}, 630 \mathrm{~T}>\mathrm{C}, 632 \mathrm{~A}>\mathrm{C})$. Moreover, the SNPs at nt489, nt516, nt624, nt630 and nt632 are in complete linkage disequilibrium: with GGT TA always together and AAC CC always together. The discovered sequence of the first missense mutation $(236 \mathrm{C}>\mathrm{G})$ was deposited in GenBank (acc no. GQ144334; size: 593 bp; primers: P1-F1/P2-R1), the complete linkage of five SNPs were deposited in GenBank (acc no. FJ794270; size: 972 bp; primers: P1-F1/P1-R2). The variation at two SNP loci caused amino acid mutation 236C>G: Ser to Cys; 632A>C: Glu to Asp, respectively. While variation at the other four SNPs loci were synonymous mutations. Two SNPs (236C $>$ G and $516 \mathrm{G}>\mathrm{A}$ ) were genotyped among four cattle populations by forced PCR-RFLP methods. The genotypic frequencies of two SNP loci in the Chinese Holstein population agreed with Hardy-Weinberg equilibrium 
$(P>0.05)$ (Table 1). The association of six mutations with body weight and average daily gain of Nanyang and Jiaxian were analyzed together. The statistical model:

$$
Y_{i j k l}=\mu+A_{i}+G_{j}+e_{i j k}
$$

where $Y_{i j k}$ is the trait measured on each of the $i j k$-th animal, $\mu$ is the overall population mean, $A_{i}$ is the fixed effect due to the $i$-th age, $G_{j}$ is the fixed effect associated with $j$-th genotype and $e_{i j k}$ is the random error. The least square means estimates (LSM) with standard errors for three genotypes and growth traits were used. The result indicated that the first missense mutation $(236 \mathrm{C}>\mathrm{G})$ genotype was significantly associated with body weight and average daily gain. The individuals with GG genotype had higher body weight and average daily gain than the individuals with CG and CC genotypes $(P<0.05)$ (Table 2). However, the five linked mutations (489G $>A, 516 G>A, 624 T>C, 630 T>C$, $632 \mathrm{~A}>C)$ were not statistically significantly associated with growth traits $(P>0.05)$.

Table 1

Genotype distribution and allelic frequencies at NPM1 gene in cattle

Genotypen-Verteilung und relative Allelehäufigkeit des NPM1-Gens beim Rind

\begin{tabular}{lcrrrrrrr}
\hline \multirow{2}{*}{ SNP/Amino acid change } & \multirow{2}{*}{ Breeds } & \multicolumn{4}{c}{ Observed Genotypes } & \multicolumn{4}{c}{ Allelic frequencies } & $\chi^{2}$ \\
& & CC & CG & GG & Total & C & \multicolumn{1}{c}{ G } & (HWE) \\
\hline \multirow{3}{*}{ 236C $>$ G/Ser43Cys } & NY & 170 & 63 & 29 & 262 & 0.769 & 0.231 & $P<0.05$ \\
& QC & 184 & 36 & 15 & 235 & 0.86 & 0.14 & $P<0.05$ \\
& JX & 257 & 123 & 61 & 441 & 0.722 & 0.278 & $P<0.05$ \\
& CH & 81 & 11 & 2 & 94 & 0.92 & 0.08 & $P>0.05$ \\
& & WW & WM & MM & & W & M & \\
516G $>$ A/Leu136Leu & NY & 128 & 84 & 50 & 262 & 0.649 & 0.351 & $P<0.05$ \\
& QC & 119 & 86 & 30 & 235 & 0.689 & 0.311 & $P>0.05$ \\
& JX & 264 & 107 & 70 & 441 & 0.72 & 0.28 & $P<0.05$ \\
& CH & 88 & 6 & 0 & 94 & 0.968 & 0.032 & $P>0.05$ \\
\hline
\end{tabular}

$\chi 2$ (HWE) Hardy-Weinberg equilibrium $\chi 2$ value, $P>0.05$ showed that the SNP locus in the population was at Hardy-Weinberg equilibrium. NY Nanyang breed, QC QinChuan breed, JX Jiaxian breed, CH Chinese Holstein breed

Table 2

Associations of different genotypes within the NPM1 gene with growth traits in cattle Genotypen-Verteilung und relative Allelehäufigkeit des NPM1 beim Rind

\begin{tabular}{|c|c|c|c|c|c|c|}
\hline \multirow{2}{*}{ Breeds } & \multirow{2}{*}{ Ages } & \multirow{2}{*}{ Traits } & \multicolumn{3}{|c|}{ Genotypes at NPM1 gene $(236 \mathrm{C}>\mathrm{G})$} & \multirow{2}{*}{$P$-value } \\
\hline & & & CC (Mean $\pm \mathrm{SE})$ & $\mathrm{CG}($ Mean $\pm \mathrm{SE})$ & GG (Mean \pm SE) & \\
\hline \multirow{2}{*}{$J X$} & \multirow{2}{*}{6 months } & $\mathrm{BW}, \mathrm{kg}$ & $161.90 \pm 8.82^{\mathrm{a}}$ & $167.59 \pm 5.12^{\mathrm{a}}$ & $182.63 \pm 4.21^{b}$ & 0.027 \\
\hline & & $A D G, g$ & $747.00 \pm 48.00^{\mathrm{a}}$ & $775.00 \pm 28.00^{\mathrm{a}}$ & $857.00 \pm 23.00^{\mathrm{b}}$ & 0.029 \\
\hline NY & 18 months & $\mathrm{BW}, \mathrm{kg}$ & $284.07 \pm 7.66^{\mathrm{a}}$ & $293.80 \pm 4.84^{\mathrm{ab}}$ & $305.80 \pm 4.05^{b}$ & 0.024 \\
\hline
\end{tabular}

JX Jiaxian breed, NY Nanyang breed, BW body weight, ADG average daily gain, mean least square means, SE standard error of the means, Values with different superscripts within the same line differ significantly at ${ }^{\mathrm{a}, \mathrm{b}} P<0.05$.

\section{Acknowledgements}

This study was supported by the National 863 Program of China (No. 2006AA10Z197, 2008AA101010), National Natural Science Foundation of China (No. 30771544, 30972080), National Key Technology R\&D Program (No. 2008ADB2B03-19), Keystone Project of 
transfergene in China (No. 2009ZX08009-157B, No. 2008ZX08007-002), »13115« Sci-Tech Innovation Program of Shaanxi Province (No. 2008ZDKG-11), Program of National Beef Cattle Industrial Technology System, Basic and Foreland Technology Study Program of Henan Province (No. 072300430160).

\section{References}

Grisendi S, Mecucci C, Falini B, Pandolfi PP (2006) Nucleophosmin and cancer. Nat Rev Cancer 6, 493-505

Huang YZ, Zhang EP, Chen H, Wang J, Li ZJ, Huai YT, Ma L, Lan XY, Ren G, Lei CZ, Fang XT, Wang JQ (2010) Novel 12-bp deletion in the coding region of the bovine NPM1 gene affects growth traits. J Appl Genet 51, 199-202

Maggi LBJ, Kuchenruether M, Dadey DY, Schwope RM, Grisendi S, Townsend RR, Pandolfi PP, Weber JD (2008) Nucleophosmin serves as a rate-limiting nuclear export chaperone for the mammalian ribosome. Mol Cell Biol 23, 7050-65

Naoe T, Suzuki T, Kiyoi H, Urano T (2006) Nucleophosmin: a versatile molecule associated with hematological malignancies. Cancer Sci 97, 963-9

Wang XL, Lan XY, Lai XS, Wang KY, Yu H, Wang M, Guo YK, Lei CZ, Chen H (2009) A novel mutation of the GLI2 gene associated with body weight in bovine (Bos taurus). Arch Tierz 52, 334-6

Received 1 May 2009, accepted 25 June 2010.

Corresponding author:

HONG CHEN

email: chenhong1212@263.net

College of Animal Science and Technology, Northwest A\&F University, Yangling, No. 22 Xinong Road, Shaanxi 712100, People's Republic of China 